\title{
Impact of salinity and growth phase on alkenone distributions in coastal haptophytes
}

David Chivall, Daniela M’Boule, Daniëlle Sinke-Schoen, Jaap S. Sinninghe Damsté, Stefan Schouten, Marcel T.J. van der Meer

NIOZ Royal Netherlands Institute for Sea Research

Department of Marine Organic Biogeochemistry

PO Box 59

1790 AB Den Burg

Netherlands

${ }^{*}$ Corresponding author. Tel.: +31222369409

Email address: david.chivall@nioz.nl

\section{NOTICE}

This is the authors' version of a work that was accepted for publication in Organic Geochemistry. Changes resulting from the publishing process, such as peer review, editing, corrections, structural formatting, and other quality control mechanisms may not be reflected in this document. Changes may have been made to this work since it was submitted for publication. A definitive version was subsequently published in

Organic Geochemistry 67 (2014), 31-34. doi:10.1016/j.orggeochem.2013.12.002

The data used in this manuscript is available at

http://doi.pangaea.de/10.1594/PANGAEA.823603

\begin{abstract}
Batch cultures of Isochrysis galbana (strain CCMP 1323) and Chrysotila lamellosa (strain CCMP 1307) were grown at salinity values of ca. 10 to ca. 35 and the alkenone distributions determined for different growth phases. $\mathrm{U}_{37}^{\mathrm{K}}$ values decreased slightly with salinity for $C$. lamellosa but were largely unaffected for I. galbana except during the decline phase. The values decreased with incubation time in both species. The proportion of $\mathrm{C}_{37: 4}$ used as a proxy for salinity, increased in both species at $0.16-0.20 \%$ per salinity unit, except during the stationary phase for I. galbana. $\mathrm{C}_{37: 4}$ was much more abundant in C. lamellosa (30$44 \%$ ) than in I. galbana (4-12\%). Although our results suggest that salinity has a direct effect on alkenone distributions, growth phase and species composition should also have a marked impact, complicating the use of alkenone distributions as a proxy for salinity in the marine environment.
\end{abstract}




\section{Introduction}

Long chain alkenones are produced exclusively by a few species of marine (Volkman et al., 1980; Marlowe et al., 1984; Volkman et al., 1995) and lacustrine (e.g. Coolen et al., 2004; D’Andrea et al., 2006; Theroux et al., 2010) haptophyte algae and have been extensively studied because of the widespread application of the unsaturation indices $U_{37}^{K}$ (Brassell et al., 1986) and $\mathrm{U}_{37}^{\mathrm{K}}$ (Prahl and Wakenham, 1987) as palaeotemperature proxies. Besides temperature, alkenone distributions also vary with other factors including species (e.g. Marlowe et al., 1984), growth phase (Conte et al., 1998) and salinity (Ono et al., 2012).

There is interest in using the distributions as a proxy for salinity. An increased relative abundance of the $\mathrm{C}_{37: 4}$ alkenone as a proportion of the total abundance of $\mathrm{C}_{37}$ alkenones $\left(\% \mathrm{C}_{37: 4}\right)$ has been observed with decreased salinity in marine (Rosell-Melé, 1998; Schulz et al., 2000; Blanz et al., 2005) and lacustrine (Liu et al., 2008; 2011) environments and has been suggested as a salinity proxy. However, sometimes none or an opposite relationship with salinity has been observed (Sikes and Sicre, 2002; Theroux et al., 2010; Toney et al., 2010; Schwab and Sachs, 2011), possibly because $\% \mathrm{C}_{37: 4}$ varies in different alkenone-producing species and strains (Marlowe et al., 1984; Conte et al., 1995). Interestingly, however, only one study has examined the direct effect of salinity on alkenone distributions in culture (Ono et al., 2012).

We have therefore grown batch cultures of the major coastal alkenone-producing haptophytes, Isochrysis galbana and Chrysotila lamellosa, which are phylogenically related to lacustrine alkenone producers (Coolen et al., 2004; Theroux et al., 2010), and studied their alkenone distributions at different salinity values and at different growth phases.

\section{Material and methods}

Batch cultures of I. galbana (strain CCMP 1323) and C. lamellosa (strain CCMP 1307) were grown in triplicate in $\mathrm{f} / 2$ media (Guillard, 1975) at six salinity values between 10.2 and 35.5. Cultures $(600 \mathrm{ml})$ were grown at $15^{\circ} \mathrm{C}$ receiving $60 \mu \mathrm{mol}$ photons $\mathrm{m}^{-2} \mathrm{~s}^{-1}$, with a light:dark cycle of 16:8 h. Cell density was monitored using flow cytometry (Accuri C6). I. galbana cell material was collected using filtration onto precombusted $0.7 \mu \mathrm{m} \mathrm{GF} / \mathrm{F}$ filters, after 10 (exponential growth phase), 27 or 28 (stationary phase) and 69, 75, 83, or 89 days (decline phase). C. lamellosa was collected after 14 or 15 (early stationary phase) and 35 days (late stationary phase). After addition of an $n$-nonadecan-10-one internal standard, freeze-dried filters were extracted with 2:1 v/v dichloromethane (DCM)/MeOH $\left(4 \times 10 \mathrm{ml} ; 4 \times 5 \mathrm{~min}\right.$ sonication). The extract was separated using an $\mathrm{Al}_{2} \mathrm{O}_{3}$ column into three fractions: apolar (eluted with 9:1 v/v hexane/DCM), alkenone (1:1 v/v hexane/ $\mathrm{DCM})$ and polar $(1: 1 \mathrm{v} / \mathrm{v} \mathrm{DCM} / \mathrm{MeOH})$. The alkenone fraction was analysed using gas chromatography (GC) with an Agilent 6890 instrument equipped with an Agilent CP-Sil $5 \mathrm{CB}$ column $(50 \mathrm{~m} \times 0.32 \mathrm{~mm}$ i.d.; $0.12 \mu \mathrm{m}$ film thickness). The temperature program was: 70 to $200^{\circ} \mathrm{C}$ at $20^{\circ} \mathrm{C} \mathrm{min}-1$, then at $3^{\circ} \mathrm{C} \mathrm{min}{ }^{-1}$ to $320^{\circ} \mathrm{C}$ (held $25 \mathrm{~min}$ ). Components were identified using GC-mass spectrometry (GC-MS) with an Agilent 7890A GC instrument and Agilent 5975C VL mass selective detector (MSD).

\section{Results and discussion}

The mean $\mathrm{U}_{37}^{\mathrm{K}}$ and $\% \mathrm{C}_{37: 4}$ of alkenones for I. galbana and C. lamellosa grown in triplicate over a range of salinity and sampled during different growth phases are displayed in Table 1 and Fig. 1.

Mean $\mathrm{U}_{37}^{\mathrm{K}^{\prime}}$ for $I$. galbana was $0.11 \pm 0.01$ in the exponential phase, decreased to $0.07 \pm 0.01$ 
in the stationary phase and again to $0.03 \pm 0.01$ during the decline phase (Fig. 1a). There was no significant relationship between $U_{37}^{K^{\prime}}$ and salinity in the exponential $(p=0.08)$ and stationary $(p=0.19)$ growth phases, in accord with a recent study (Ono et al., 2012). However, there was a significant decrease of $5 \times 10^{-4}$ per unit salinity $\left(\mathrm{S}^{-1}\right)$ in the decline phase $\left(R^{2}=0.75\right)$. Like I. galbana, $\mathrm{U}_{37}^{\mathrm{K}}$ for C. lamellosa decreased with incubation time from $0.08 \pm 0.01$ in the early stationary phase to $0.07 \pm<0.01$ in the late stationary phase (paired one-tailed t-test, $p<0.001$; Fig. 1b; cf. Rontani et al., 2004). In contrast to results from $I$. galbana, $\mathrm{U}_{37}^{\mathrm{K}^{\prime}}$ values for $C$. lamellosa decreased with increasing salinity during both the early and late stationary phase by $8 \times 10^{-4} S^{-1}\left(R^{2}=0.66\right)$ and $2 \times 10^{-4} S^{-1}\left(R^{2}=0.26 ; p=0.03\right)$, respectively.

In I. galbana, $\% \mathrm{C}_{37: 4}$ increased with salinity by $0.19 \% \mathrm{~S}^{-1}\left(R^{2}=0.62\right.$; Fig. $\left.1 \mathrm{c}\right)$ and $0.20 \% \mathrm{~S}^{-1}$ $\left(R^{2}=0.86\right)$ in the exponential phase and decline phase, respectively, but there was no significant relationship during the stationary phase $(p=0.49)$. There was little change in

$\% \mathrm{C}_{37: 4}$ between the exponential and decline phases $(8 \pm 2 \%$ and $7 \pm 2 \%$, respectively; paired two-tailed t-test, $p=0.19)$, although $\% \mathrm{C}_{37: 4}$ was lower $(5 \pm 1 \%)$ for the stationary phase. In C. lamellosa, $\% \mathrm{C}_{37: 4}$ increased from $35 \pm 2 \%$ to $40 \pm 2 \%$ from the early to late stationary phase and also increased with salinity in both the early $\left(0.16 \% \mathrm{~S}^{-1} ; R^{2}=0.44\right.$; Fig. 1d) and late $\left(0.18 \% \mathrm{~S}^{-1} ; R^{2}=0.62\right)$ stationary phase.

Our results show that both growth phase and salinity substantially affect alkenone distributions in coastal haptophytes. The $\mathrm{U}_{37}^{\mathrm{K}^{\prime}}$ values remained constant or decreased by $<1 \times 10^{-3} \mathrm{~S}^{-1}$ (equivalent to $<0.03{ }^{\circ} \mathrm{CS}^{-1}$ using the Müller et al., 1998 calibration), so changes in salinity are unlikely to affect temperature reconstruction. In contrast, growth phase had a large impact on $\mathrm{U}_{37}^{\mathrm{K}}$ values, with a reduction of up to 0.08 observed after the exponential phase (cf. Prahl et al., 2003). Importantly, we have shown direct evidence for a physiological response of $\mathrm{C}_{37: 4}$ to changing salinity in individual algal strains: there was a consistent increase in $\% \mathrm{C}_{37: 4}$ with salinity for both species in most growth phases. The biochemical mechanisms behind this response are uncertain but may be related to an adaptation in buoyancy regulated by lipid bodies (cf. Pond, 2012). The increase in $\% \mathrm{C}_{37: 4}$ with salinity in our cultures contrasts with the general observation that $\% \mathrm{C}_{37: 4}$ decreases at higher salinity (e.g. Rosell-Melé, 1998), although increasing $\%_{37: 4}$ with salinity has been observed for Chesapeake Bay (Schwab and Sachs, 2011). These apparently contradictory observations might be reconciled by considering the large difference between $\% \mathrm{C}_{37: 4}$ for the two coastal species reported here (C. lamellosa: 30-44\%; I. galbana: 4-12\%) as well as $\% \mathrm{C}_{37: 4}$ for other marine species (Emiliania huxleyi, <6\%; Gephyrocapsa oceanica, <1\%; Conte et al., 1995). Changes in species composition may account for a decreasing trend in $\% \mathrm{C}_{37: 4}$ with salinity, whereas a relatively constant species composition may account for an increasing trend (Fig. 1c and d). Meanwhile, our results also show that the effect of growth phase on $\% \mathrm{C}_{37: 4}$ can be greater than that of salinity. Therefore, unless the species composition and growth phase of alkenone producers are known, the use of alkenone distributions as a salinity proxy is uncertain.

\section{Acknowledgments}

We thank A. Noordeloos and the Department of Biological Oceanography at NIOZ for assistance with algal culturing. We thank Ken Sawada for his constructive review. This research was funded by the Netherlands Organization for Scientific Research (NWO) through Project ALW818.01.022. NWO is also acknowledged for funding M.v.d.M. (VIDI) and S.S. (VICI). 


\section{References}

Blanz, T., Emeis, K.C., Siegel, H., 2005. Controls on alkenone unsaturation ratios along the salinity gradient between the open ocean and the Baltic Sea. Geochimica et Cosmochimica Acta 69, 3589-3600.

Brassell, S.C., Eglinton, G., Marlowe, I.T., Pflaumann, U., Sarnthein, M., 1986. Molecular stratigraphy: a new tool for climatic assessment. Nature 320, 129-133.

Conte, M.H., Thompson, A., Eglinton, G., Green, J.C., 1995 Lipid biomarker diversity in the coccolithophorid Emiliania huxleyi (Prymnesiophyceae) and the related species Gephyrocapsa oceanica. Journal of Phycology 31, 272-282.

Conte, M.H., Thompson, A., Lesley, D., Harris, R.P., 1998. Genetic and physiological influences on the alkenone/ alkenoate versus growth temperature relationship in Emiliania huxleyi and Gephyrocapsa oceanica. Geochimica et Cosmochimica Acta 62, 51-68.

Coolen, M.J.L., Muyzer, G., Rijpstra, W.I.C., Schouten, S., Volkman, J.K., Sinninghe Damsté, J.S., 2004. Combined DNA and lipid analyses of sediments reveal changes in Holocene haptophyte and diatom populations in an Antarctic lake. Earth and Planetary Science Letters 223, 225-239.

D’Andrea, W.J., Lage, M., Martiny, J.B.H., Laatsch, A.D. Amaral-Zettler, L.A., Sogin, M.L., Huang, Y., 2006 Alkenone producers inferred from well-preserved $18 \mathrm{~S}$ rDNA in Greenland lake sediments. Journal of Geophysical Research-Biogeosciences 111. http://dx.doi. org/10.1029/2005jg000121

Liu, W.G., Liu, Z.H., Fu, M.Y., An, Z.H., 2008. Distribution of the $\mathrm{C}_{37}$ tetra-unsaturated alkenone in Lake Qinghai, China: A potential lake salinity indicator. Geochimica et Cosmochimica Acta 72, 988-997.

Liu, W.G., Liu, Z.H., Wang, H.Y., He, Y.X., Wang, Z., Xu, L.M., 2011. Salinity control on long-chain alkenone distributions in lake surface waters and sediments of the northern Qinghai-Tibetan Plateau, China. Geochimica et Cosmochimica Acta 75, 1693-1703.

Marlowe, I.T., Green, J.C., Neal, A.C., Brassell, S.C., Eglinton, G., Course, P.A., 1984. Long-chain $\left(n-\mathrm{C}_{37}-\mathrm{C}_{39}\right)$ alkenones in the Prymnesiophyceae. Distribution of alkenones and other lipids and their taxonomic significance. British Phycological Journal 19, 203-216.

Müller, P.J., Kirst, G., Ruhland, G., von Storch, I., Rosell-Melé, A., 1998. Calibration of the alkenone paleotemperature index $\mathrm{U}_{37}^{\mathrm{K}}$ based on core-tops from the eastern South Atlantic and the global ocean $\left(60^{\circ} \mathrm{N}-60^{\circ} \mathrm{S}\right)$. Geochimica et Cosmochimica Acta 62, 1757-1772.

Ono, M., Sawada, K., Shiraiwa, Y., Kubota, M., 2012. Changes in alkenone and alkenoate distributions during acclimatization to salinity change in Isochrysis galbana: Implication for alkenone-based paleosalinity and paleothermometry. Geochemical Journal 46, 235-247.
Pond, D.W., 2012. The physical properties of lipids and their role in controlling the distribution of zooplankton in the oceans. Journal of Plankton Research 34, 443-453.

Prahl, F.G., Wakeham, S.G., 1987. Calibration of unsaturation patterns in long-chain ketone compositions for paleotemperature assessment. Nature 330, 367-369.

Prahl, F.G., Wolfe, G.V., Sparrow, M.A., 2003. Physiological impacts on alkenone paleothermometry. Paleoceanography 18. http://dx.doi.org/10.1029/2002pa000803

Rontani, J.F., Beker, B., Volkman, J.K., 2004. Long-chain alkenones and related compounds in the benthic haptophyte Chrysotila lamellosa Anand HAP 17. Phytochemistry 65, 117-126.

Rosell-Melé, A., 1998. Interhemispheric appraisal of the value of alkenone indices as temperature and salinity proxies in high-latitude locations. Paleoceanography 13, 694-703.

Schulz, H.M., Schoner, A., Emeis, K.C., 2000. Long-chain alkenone patterns in the Baltic Sea - an ocean-freshwater transition. Geochimica et Cosmochimica Acta 64, 469477.

Schwab, V.F., Sachs, J.P., 2011. Hydrogen isotopes in individual alkenones from the Chesapeake Bay estuary. Geochimica et Cosmochimica Acta 75, 7552-7565.

Sikes, E.L., Sicre, M.A., 2002. Relationship of the tetra-unsaturated $\mathrm{C}_{37}$ alkenone to salinity and temperature: Implications for paleoproxy applications. Geochemistry Geophysics Geosystems 3. http://dx.doi. org/10.1029/2002gc000345

Theroux, S., D’Andrea, W.J., Toney, J., Amaral-Zettler, L., Huang, Y., 2010. Phylogenetic diversity and evolutionary relatedness of alkenone-producing haptophyte algae in lakes: Implications for continental paleotemperature reconstructions. Earth and Planetary Science Letters 300, 311-320.

Toney, J.L., Huang, Y., Fritz, S.C., Baker, P.A., Grimm, E., Nyren, P., 2010. Climatic and environmental controls on the occurrence and distributions of long chain alkenones in lakes of the interior United States. Geochimica et Cosmochimica Acta 74, 1563-1578.

Volkman, J.K., Eglinton, G., Corner, E.D.S., Forsberg, T.E.V., 1980. Long-chain alkenes and alkenones in the marine coccolithophorid Emiliania huxleyi. Phytochemistry 19, 2619-2622.

Volkman, J.K., Barrett, S.M., Blackburn, S.I., Sikes, E.L., 1995. Alkenones in Gephyrocapsa oceanica: Implications for studies of paleoclimate. Geochimica et Cosmochimica Acta 59, 513-520. 
Isochrysis galbana CCMP 1323

- Exponential $\Delta$ Stationary $\circ$ Decline
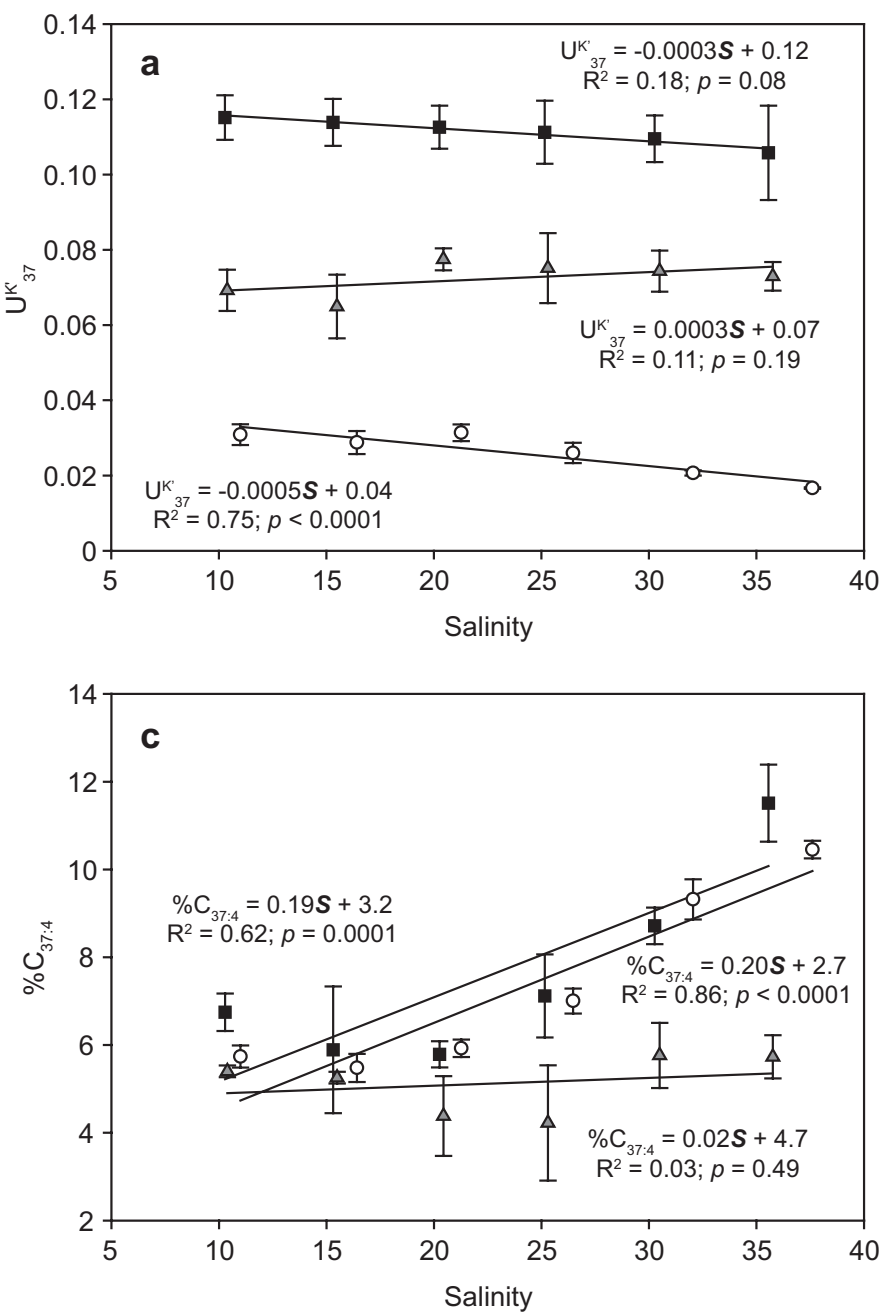

Chrysotila lamellosa CCMP 1307

\ Early stationary $\Delta$ Late stationary
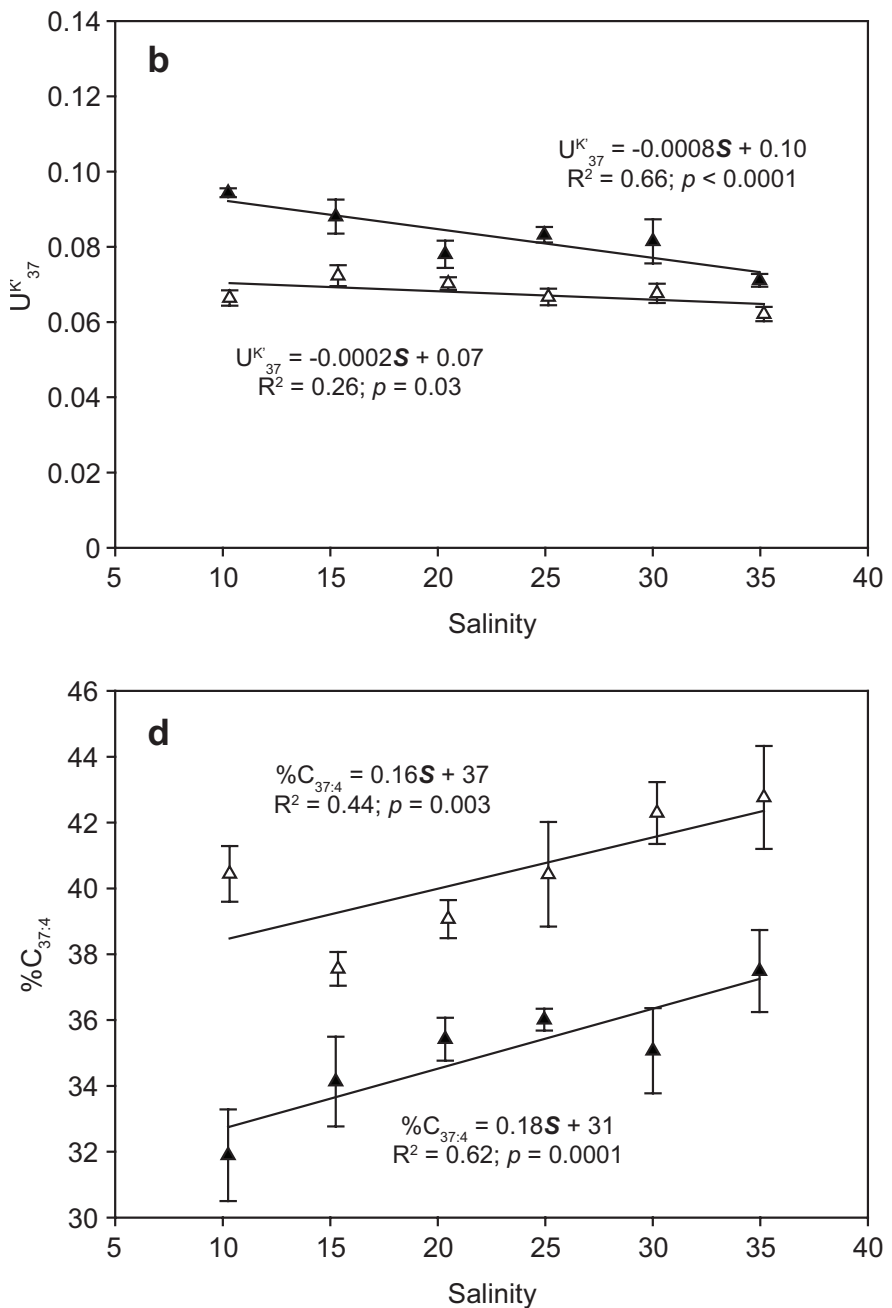

Fig. 1. $\mathrm{U}_{37}^{\mathrm{K}^{\prime}}(\mathrm{a})$ and $\% \mathrm{C}_{37: 4}$ (c; exponential phase data are from $\mathrm{M}^{\prime}$ Boule et al., unpublished results) vs. salinity for I. galbana, and $\mathrm{U}_{37}^{\mathrm{K}}$ (b) and $\% \mathrm{C}_{37.4}$ (d) vs. salinity for C. lamellosa. Values are the mean of triplicate cultures; error bars are $\pm 1 \sigma$. 
Table 1

Results from I. galbana and C. lamellosa grown at different salinity at $15^{\circ} \mathrm{C}\left(\mathrm{U}_{37}^{\mathrm{K}}\right.$ values are the mean \pm $1 \sigma$ of triplicate cultures; $\pm 1 \sigma$ for growth rate and $\mathrm{U}_{37}^{\mathrm{K}^{\prime}}$ are $0.01 \leq \sigma \leq 0.02$ and $\sigma \leq 0.01$, respectively; $\% \mathrm{C}_{37: 4}$ data for I. galbana at 10 days are from M'Boule et al., unpublished results).

\begin{tabular}{|c|c|c|c|c|c|}
\hline Salinity & $\begin{array}{l}\text { Incubation time } \\
\text { (d) }\end{array}$ & $\begin{array}{l}\text { Growth rate } \\
\left(\mathrm{d}^{-1}\right)\end{array}$ & $\mathrm{U}_{37}^{\mathrm{K}^{\prime}}$ & $\% \mathrm{C}_{37: 4}$ & $\begin{array}{l}\mathrm{C}_{37} \text { alkenone concentration } \\
\left(\mathrm{pg} \text { cell }^{-1}\right)\end{array}$ \\
\hline \multicolumn{6}{|c|}{ I. galbana } \\
\hline 10.3 & 10 & 0.63 & 0.12 & $6.7 \pm 0.4$ & $0.27 \pm 0.05$ \\
\hline 15.3 & 10 & 0.60 & 0.11 & $5.9 \pm 1.4$ & $0.39 \pm 0.14$ \\
\hline 20.3 & 10 & 0.64 & 0.11 & $5.8 \pm 0.3$ & $0.36 \pm 0.12$ \\
\hline 25.2 & 10 & 0.62 & 0.11 & $7.1 \pm 1.0$ & $0.37 \pm 0.05^{\mathrm{a}}$ \\
\hline 30.3 & 10 & 0.63 & 0.11 & $8.7 \pm 0.4$ & $0.42 \pm 0.13$ \\
\hline 35.6 & 10 & 0.62 & 0.11 & $12 \pm 0.9$ & $0.33 \pm 0.03$ \\
\hline 10.3 & 28 & & 0.07 & $5.4 \pm 0.1$ & $1.08 \pm 0.11$ \\
\hline 15.4 & 28 & & 0.06 & $5.3 \pm 0.1$ & $1.32 \pm 0.24^{\mathrm{a}}$ \\
\hline 20.4 & 27 & & 0.08 & $4.4 \pm 0.9$ & $0.95 \pm 0.30$ \\
\hline 25.3 & 28 & & 0.08 & $4.2 \pm 1.3$ & $0.69 \pm 0.25^{\mathrm{a}}$ \\
\hline 30.5 & 28 & & 0.07 & $5.8 \pm 0.7$ & $0.90^{\mathrm{b}}$ \\
\hline 35.8 & 27 & & 0.07 & $5.7 \pm 0.5$ & $0.74 \pm 0.03$ \\
\hline 10.7 & 69 & & 0.03 & $5.7 \pm 0.3$ & $0.91 \pm 0.21^{\mathrm{a}}$ \\
\hline 16.0 & 69 & & 0.03 & $5.5 \pm 0.3$ & $1.23 \pm 0.13$ \\
\hline 21.1 & 75 & & 0.03 & $5.9 \pm 0.2$ & $1.94 \pm 0.38$ \\
\hline 26.3 & 83 & & 0.03 & $7.0 \pm 0.3$ & $1.89 \pm 0.30$ \\
\hline 31.8 & 89 & & 0.02 & $9.3 \pm 0.5$ & $1.84 \pm 0.34$ \\
\hline 37.4 & 89 & & 0.02 & $10 \pm 0.2$ & $1.63 \pm 0.05$ \\
\hline \multicolumn{6}{|c|}{ C. lamellosa } \\
\hline 10.2 & 14 & & 0.09 & $32 \pm 2$ & \\
\hline 15.3 & 14 & & 0.09 & $34 \pm 2$ & \\
\hline 20.3 & 14 & & 0.08 & $35 \pm 1$ & \\
\hline 25.0 & 15 & & 0.08 & $36 \pm<1$ & \\
\hline 30.0 & 15 & & 0.08 & $35 \pm 1$ & \\
\hline 35.0 & 15 & & 0.07 & $37 \pm 1$ & \\
\hline 10.2 & 35 & & 0.07 & $40 \pm 1$ & \\
\hline 15.3 & 35 & & 0.07 & $38 \pm 1$ & \\
\hline 20.5 & 35 & & 0.07 & $39 \pm 1$ & \\
\hline 25.1 & 35 & & 0.07 & $40 \pm 2$ & \\
\hline 30.2 & 35 & & 0.07 & $42 \pm 1$ & \\
\hline 35.2 & 35 & & 0.06 & $43 \pm 2$ & \\
\hline
\end{tabular}

${ }^{\mathrm{a}}$ Mean from two cultures; reported error is the range; ${ }^{\mathrm{b}}$ from one culture. 